\title{
Post-war sustainable housing design strategies: the case of reconstruction in Iraq
}

\author{
Hala Ali Abdulrazaq and Manuel Correia Guedes* \\ Instituto Superior Técnico, University of Lisbon, Portugal
}

Received: 27 March 2021 / Received in final form: 14 June 2021 / Accepted: 14 June 2021

\begin{abstract}
The damage of architecture in Iraq has been caused by a series of wars during the last four decades. The last conflict against the Islamic State from 2014 to 2017 caused severe destruction to the buildings in seven governorates, namely: Nineveh, Baghdad, Anbar, Babel, Kirkuk, Diyala, Salah Aldeen. three years after the Iraqi government has announced liberation, the cities are still covered by tons of rubble and thousands of people are still staying in camps. Several international humanitarian organizations are providing urgent assistance to help some local people to rebuild their homes. This paper presents initial results of an ongoing $\mathrm{PhD}$ research, which focuses on the role of architectural design in the postwar reconstruction in Iraq. It addresses an architectural damage assessment of the Post-War in the Old City of Mosul, after liberation from ISIS in 2017. The damage assessment focuses the residential buildings as it is the most affected sector and the most needed to start re-building. As rubble is the main obstacle for the residents besides that it's the first step for the recovery, this paper studies the scale of destruction to determine the quantity and quality of rubble in this historic city. Thus, it presents the current actions taken by locals and examines the government movements towards rubble management. Results show that, the unguided strategy of rebuilding is inefficient causing more damage to the environment and there is no comprehensive plan to protect historic buildings with a high heritage. The aim of this paper is to provide basic guidelines and recommendations for preventing further destruction to the heritage of the Old City.
\end{abstract}

\section{Introduction: brief historical overview}

Iraq has long been known as the 'cradle of civilization', home to more than 10000 cultural sites ranging from the 5500 year old sites of Sumer, to archaeological remains of the Akkadian, Babylonian, Assyrian and Parthian cultures. Baghdad, Nineveh, Babylon and a few more cities in Iraq were greatest capitals of the ancient empires and enjoyed a golden age of architectural achievements.

These cities have suffered as a result of continuous civil and international wars; dictatorship regime; economic sanctions; ethnic and religious conflicts after the fall of Baath regime; rampant corruption; dictatorship regime; economic sanctions; rampant corruption some thirty years before it was officially occupied by ISIL. Finally, the fall of Iraq under ISIL control just worsened the situation. In conclusion, the reconstruction can be a chance to build

\footnotetext{
* e-mail: manuel.guedes@tecnico.ulisboa.pt
}

back better with two main goals: achieving architectural heritage protection and avoiding further damage to the environment.

The Iraq War was a protracted armed conflict that began in 2003 with the invasion of Iraq by a United Statesled coalition that overthrew the government of Saddam Hussein. The conflict continued for much of the next decade as an insurgency emerged to oppose the occupying forces and the post-invasion Iraqi government. An estimated 151000 to 1033000 Iraqis were killed in the first three to four years of conflict [1]. US troops were officially withdrawn in 2011. The invasion and occupation led to sectarian violence, which caused widespread displacement among Iraqi civilians. The Iraqi Red Crescent organization estimated the total internal displacement was around 2.3 million in 2008, with as many as 2 million Iraqis having left the country [2].

As the conflict neared, the Archaeological Institute of America, the International Council of Museums, the International Committee of the Blue Shield and other 
professional organizations issued public warnings, reminding U.S. leaders of their responsibilities under international law, notably the 1954 Hague Convention for the Protection of Cultural Properties in the Event of Armed Conflict [3]. They urged that protection of Iraq's cultural sites and institutions be a high priority for the occupying forces.

Significant steps were taken by academics and military planners to identify and locate sites in order to avoid targeting or causing needless collateral damage to archaeological or cultural sites during pre-invasion target planning. Given the extent of the air campaign, little substantial damage occurred to cultural property by U.S. forces during the first phase of the air campaign (March to April 2003) and during the high-speed ground campaign that culminated in the fall of the Saddam regime on April 9, 2003 [4]. The most significant losses began on April 10th, as outlined below [5].

By all accounts available at present, Coalition troops that captured Baghdad and other Iraqi cities in early April 2003 did not act to protect cultural sites. They neither took up protective positions at major cultural sites in the cities and archaeological sites in the countryside, nor did they prevent acts of looting and destruction, even when asked to do so by concerned civilians.

Attacks on the heritage sites began soon after the old regime collapsed, as part of widespread looting and destruction of government buildings and other targets. Archaeologists and Near East experts had warned that looting would begin as soon as public order broke down, just as it did in the aftermath of Operation Desert Storm, when several regional museums were looted.

While the cultural damage (looting and intentional destruction by civilians) caused by Coalition inaction may be greater in scope, damage to important cultural sites caused by misguided Coalition action is no less significant. Significant collateral damage occurred as a direct result of insurgents unmaking first military use of protected cultural property. Examples include the central area of the holy city of Najaf, destroyed in a confrontation of Coalition forces with Mahdi Army irregulars in August 2004; coalition bombardment which destroyed 65 mosques in the attack on Falluja in November 2004; and Coalition aerial and ground attacks that reduced cultural properties in Tal Afar, Ramadi, Samarra and a number of other cities to rubble. All of these actions involved imperative military necessity with no logical or feasible alternative.

Elsewhere, serious damage occurred to important archaeological sites, such as ancient Babylon and Ur two of the most important ancient sites in the world where the US military' built bases, installed fuel tanks and concrete walls, dug a dozen deep trenches, used heavy earth-moving equipment to build a helicopter landing pad, and dropped tons of gravel next to a Greek theatre built for Alexander the Great to create parking lots for military vehicles. In September 2003, U.S. forces handed authority over Babylon (known as Camp Alpha) to Polish troops who camped there until January 2005, when authority for the site reverted to the Iraq State Board of Antiquities and Heritage [5]. Lack of security presented the most serious challenge for reconstruction activities.
Beginning in 2003, diverse and significant actors, both domestic and international, engaged in reconstruction activities in Iraq, and the total budget committed to Iraq's reconstruction was unprecedented among post conflict operations undertaken by the international community [1]. At the Madrid Donor Conference in October 2003, the international community - represented by 38 countries, the European Commission, the International Monetary Fund, and the World Bank - announced overall and indicative pledges amounting to more than US $\$ 33$ billion in grants and loans [6].

Reconstruction brought some improvements to Iraqi livelihoods, but overall progress on service delivery was gradual and limited. This study considers the development of several key sectors after 2003-including those for electricity, oil, education, and health - to assess the impact of donor assistance on service delivery. Despite the billions of dollars spent on reconstruction, sectoral recovery has been slow and limited [2,7].

However, by mid-2014 the country was in chaos with a new government yet to be formed following national elections, and the insurgency reaching new heights. In early June 2014 the Islamic State in Iraq and the Levant (ISIL) took over the cities of Mosul. ISIL captured a third of Iraq's territory, mainly Ninewa, Anbar, Salah al-Din, Diyala, and Kirkuk. During the summer months of 2014, ISIL instigated the displacement of over half a million people from and within Nineveh. The group implemented a systematic campaign to empty the region of religious and ethnic diversity. Christians, Turkmens, Yezidis, Shabak and others faced targeted killings, abductions and persecution.

The total damage to the Housing sector in the seven assessed governorates. An approximate 138051 residential buildings are impacted. Half of these structures are destroyed beyond repair. The housing stock in Iraq consists of apartment units, single-family homes, low-income housing, and villas. The recent regional ISIL created conflict in Iraq has resulted in a humanitarian crisis with the internal displacement of over 5 million Iraqis and the destruction of infrastructure and services in the former ISIS-occupied areas. The United Nations Office for the Coordination of Humanitarian (UNOCHA) Affairs estimates that about 6.2 million people are in need of targeted humanitarian assistance, including food, shelter, clean water, sanitation services, and education support. The northern governorates are hosting a large share of Syrian refugees and Iraqi Internally Displaced Persons (IDPs). The scale and speed of the displacement as a result of the crisis make it a challenge for the government to deliver quality services, especially in the newly liberated areas where the infrastructure destruction has been most severe and service delivery has been adversely impacted.

Mosul holds the largest share of total housing damage in the seven governorates. As a result of these destructions, many distinctive architectural features have been lost (Fig. 1). For example, all Ottoman pencil-shaped minarets (well-known example: al Qalamya) which appeared at the end of 18th century in the shrines of the Prophets Johan, Gorges and Shith. The conical cupolas which were famous 


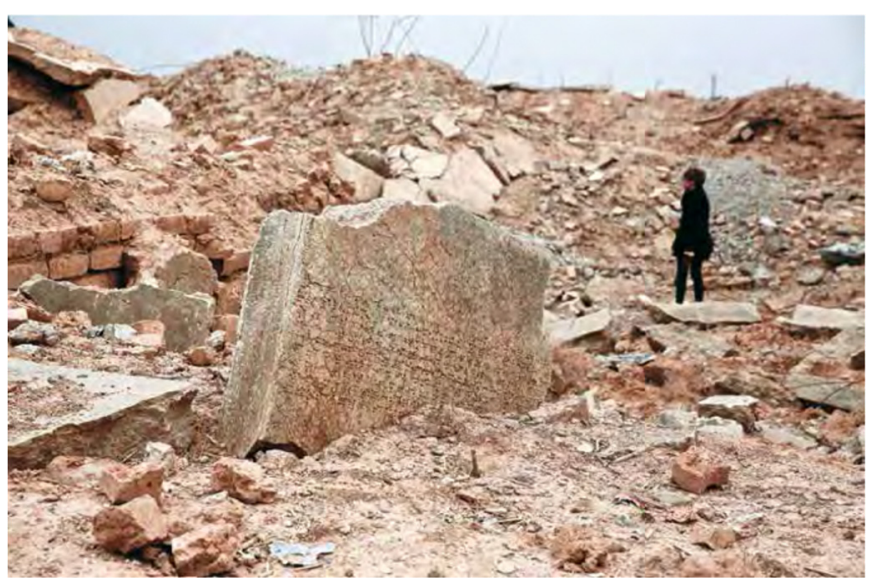

Fig. 1. Amidst the rubble a damaged stone tablet with cuneiform writing [7].

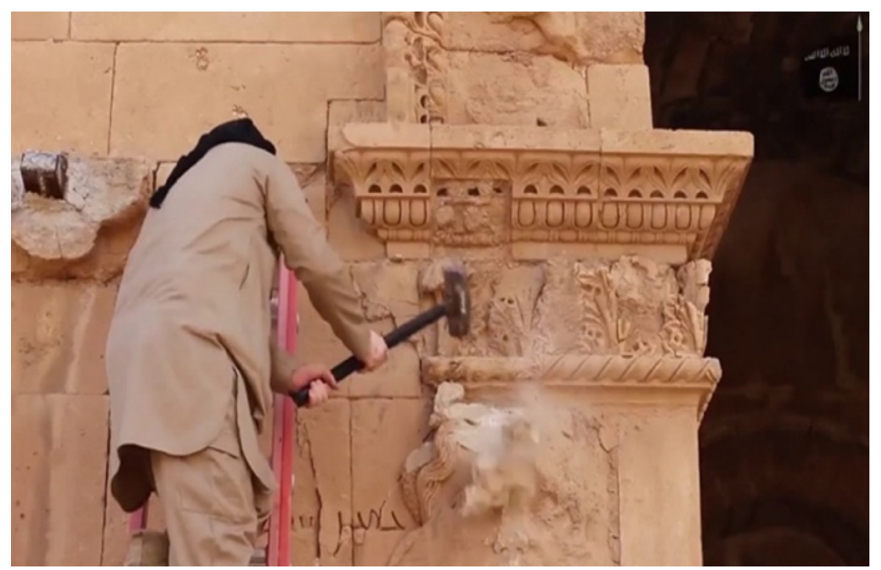

Fig. 2. ISIL militants have destroyed remains of the 2000-yearold city of Hatra, a well-preserved complex of temples south of Mosul [Associated Press].

during the Zengid age have been destroyed, except the last small one at Hassan al Bakri Mosque, in addition to countless wonderful Mihrabs and Minbars.

ISIL has conducted a systematic campaign of destruction of Mosul's cultural heritage sites and monuments in an attempt to obliterate the city's history. It has destroyed the ancient city of Nineveh, including the Palace of Sennacherib and all its monuments. It has also bulldozed the famous gates of the city and the entire $12 \mathrm{~km}$-long city wall. The Islamic State (ISIL) has released a propaganda video purportedly showing its militants taking sledgehammers to Iraq's UNESCO World Heritage city of Hatra [8]. The clip is the last in a series published by the jihadist group to advertise its iconoclastic fight against shrines, statues and artefacts of ancient civilisations, which it designates as "false idols" to be destroyed according to a strict interpretation of Islamic Law (Fig. 2). The slick sevenminute footage titled "smashing idols" begins with aerial footage of what appears to be the 2000-year-old archaeological site in Iraq's Nineveh governorate, some $290 \mathrm{~km}$ north-west of Baghdad.
Furthermore, the damage to Mosul's cultural heritage during military efforts to oust ISIL from Mosul and the surrounding areas is severe. Parts of the Old City have been completely destroyed in the final phase of liberation. Several months of armed conflict in the struggle to retake the city has left behind a devastated urban landscape, characterised by destroyed monuments, demolished houses, damaged buildings, destroyed infrastructure, extensive piles of rubble and areas contaminated by human bodies and unexploded ordnance.

\section{Case study: Mosul}

Since the liberation of Iraq in 2017, humanitarian actors have been providing emergency assistance to rehabilitate infrastructure and public facilities. However, several actors, including Nineveh's Governorate, and international actors have expressed their concern that reconstruction without a coordinated strategy is inefficient and may complicate the long-term development of the city. Indeed, the recovery and reconstruction of the architecture in Iraq would greatly benefit from a guiding framework that supports the architects with the postwar design strategies. This research aims to define recovery priorities and deliver a comprehensive reconstruction and planning approach. It aims to provide concrete actions for the revival of the entire Mosul metropolis, supported by desk research, fieldwork, and data. In addition, it will provide recommendations for the implementation of suggested actions and provides an analysis of the current reconstruction and recovery activities in Mosul and highlights emerging needs for the heritage recovery.

The construction damage to the Old City in Mosul during the military efforts to liberate the city from ISIS (Islamic State in Iraq and Syria) is severe (Fig. 3). In the final phase of the liberation, parts of the Old City have been completely destroyed [9]. Mosul has been liberated since 2017, but still there are approximately 15000 families currently living in camps. The housing sector is the most affected among others in the Old City.

The massive quantity of rubble resulted from the destruction prevents the families to return. According to officials from the government in Mosul, there are still no actions taken by the government regarding rubble management and housing rehabilitation.

Due to the urgent need of people to return, there are few housing rehabilitation projects going on by UNESCO, UNHabitat, UNHCR and Norwegian Refugee Council, also there is an ongoing self-rebuilding process by locals. This unplanned process is resulting in long term problems such as; unsupervised disposal of rubble is resulting in throwing rubble in the river and in different sites around the city. There are some public landmarks with high heritage value like mosques and churches are being used as disposal sites by the locals which leads to further destruction to the heritage. The unplanned relocation of rubble forms a safety risk, as there are still many sites that have not been cleared from unexploded ordnance.

The rebuilding process by people is causing the use of foreign building materials because local materials are not 

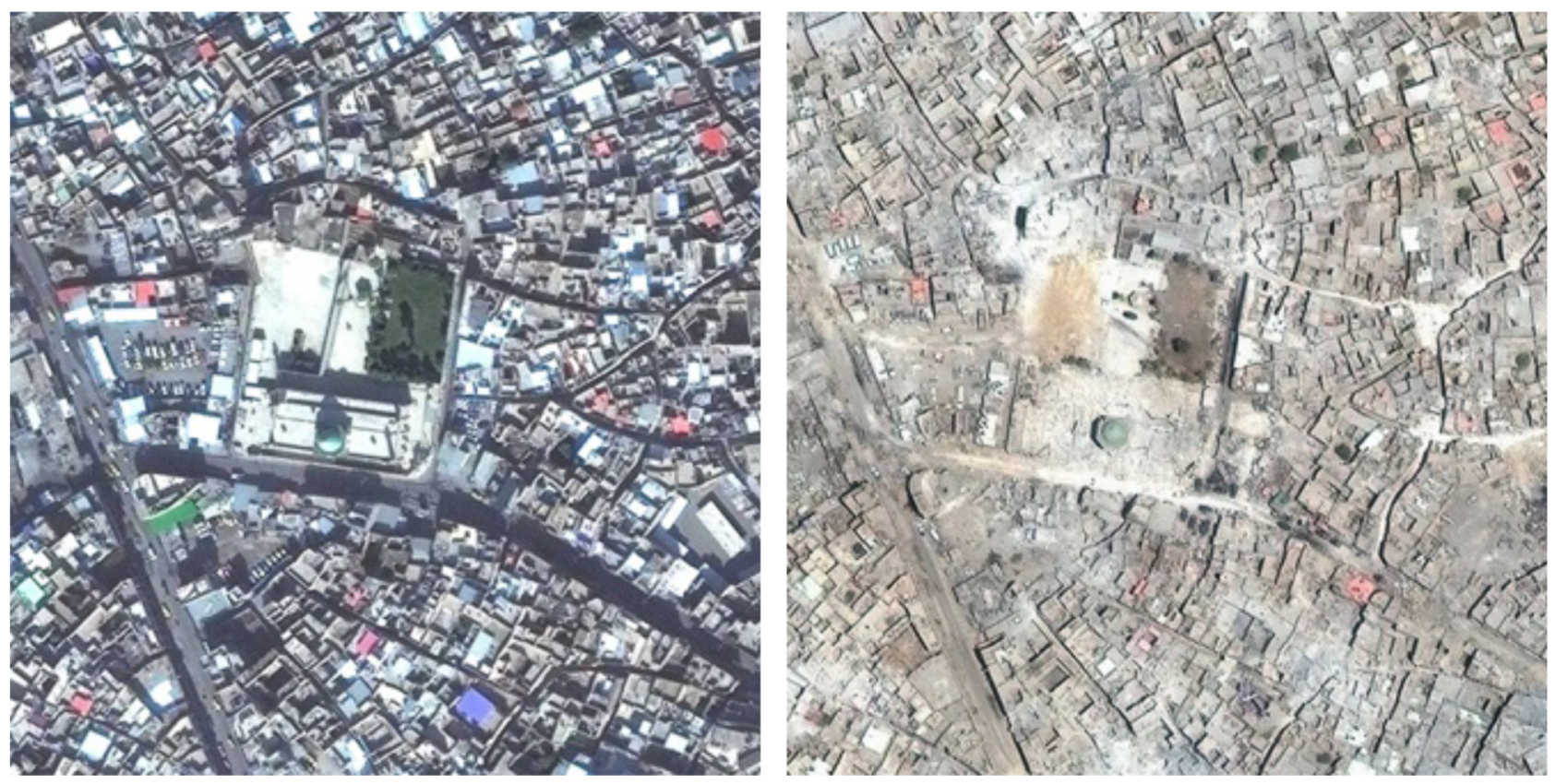

Fig. 3. Satellite picture showing Al Nuri Mosque area with the surrounding residential buildings before (in the left) and after (right) the strikes [left google maps, right: earth explorer].
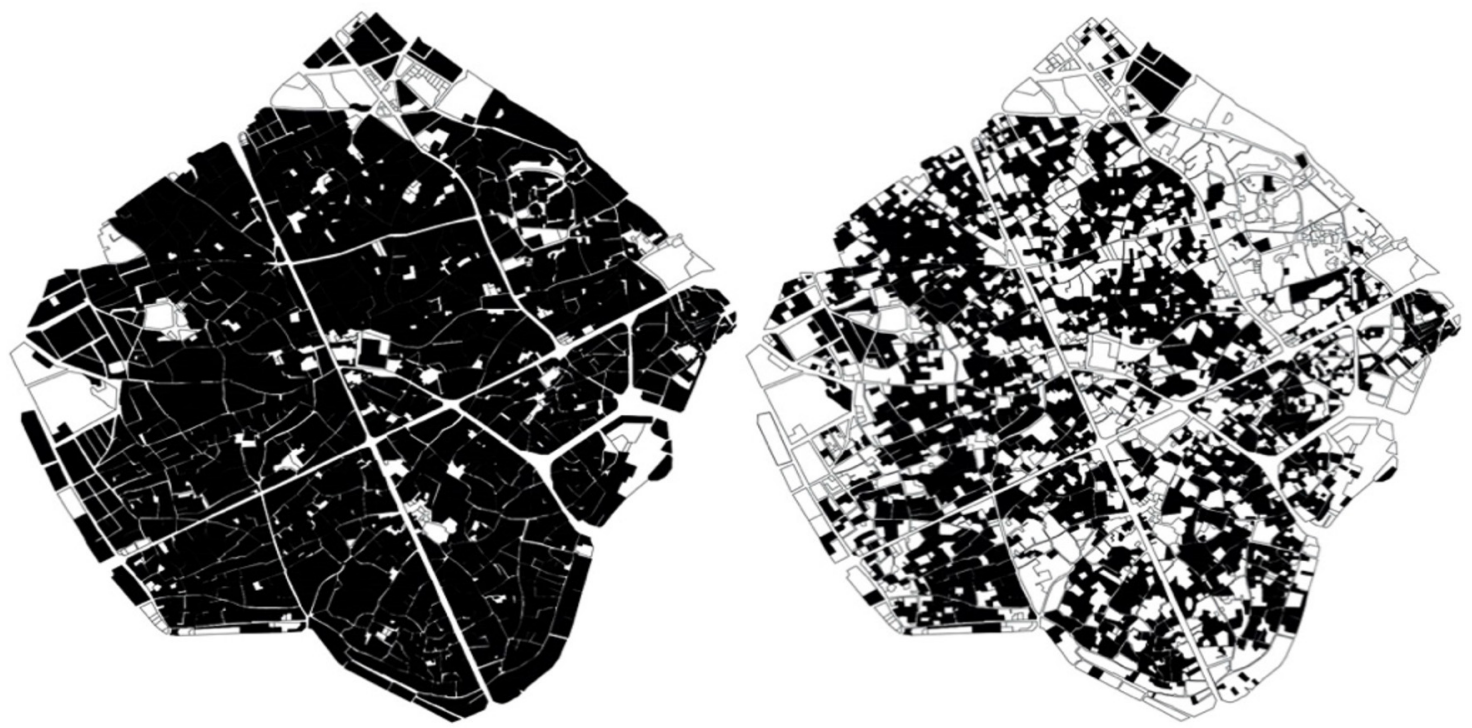

Fig. 4. Left - Old City Plan before the conflict; right- after the conflict showing the scale of destruction, open spaces are the buildings which are severely or completely destroyed. Those are the areas that need to be cleared.

easily available. Therefore, there is an increasing demand to start a supervised recovery plan starting from rubble clearance and management.

In this paper we focus on defining rubble characterisation, quantification and distribution around the Old City in order to build a framework for the full recovery approach as the first step towards reconstruction of the city. The aim of this paper to provide concrete actions for the revival of Mosul and recommendations for the implementation of suggested actions. Supported by fieldwork and interviews with decision makers in Mosul and collected data from reports that have been done by the engineering bureau and UN agencies.

There are approximately 15000 houses in old city in Mosul (Fig. 4). The UN-Habitat has reported the degree of damage sustained. Damage assessment is defined in five grades, through the identification of primary features of the building. This classification is agreed upon by development actors working under the shelter cluster that; an inter-agency coordination mechanism that supports 
Table 1. Damage assessment levels and their descriptions.

\begin{tabular}{lll}
\hline Damage level & Number of buildings & Description \\
\hline Negligible, Minor, Major & 9455 buildings & $\begin{array}{l}\text { Walls: no damage to slight cracking with no observable } \\
\text { deformation of structural elements }\end{array}$ \\
& & Roof: slight to minor damage but roof structure is intact \\
& Windows and doors: minor damage to windows and frames. \\
& External doors missing or damaged \\
& Finishes: internal spaces by shells, fire damage can be repaired. \\
& Walls and roof: damage of the structural elements \\
& with permanent deformations \\
& & Windows and doors: damaged \\
& & Finishes: severe fire damage \\
& Walls and roof: reduced to rubble, complete failure. \\
& Extensive cracking or loss of material with gross \\
& or overall deformation, partial or complete collapse or roof \\
& & Windows and doors: damaged \\
& Finishes: severe fire damage \\
&
\end{tabular}

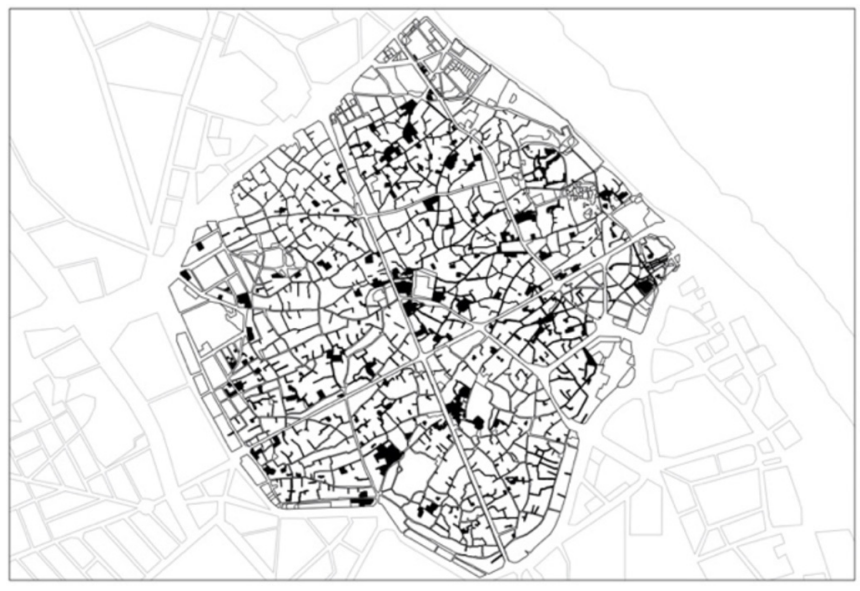

Fig. 5. Intricate small street layout of the Old City.

humanitarian shelter [9]. The damage inflict for these houses is divided into five categories: negligible, minor, major, severe, and destroyed (Tab. 1).

The distinctive vernacular architecture and the heritage architectural landmarks in the Old City, have made the city one of the most preserved areas in Iraq. The network of streets, alleyways, and cul-de-sacs represented one of the best examples of the spontaneously grown pattern of Cities in the Arab World (Figs. 5 and 6). All of the buildings, together with the domestic architecture and medieval urban plan, gave Mosul a distinctive cityscape [10].

Typical rubble in this area comprises from masonry, bricks, building stones, gypsum used in traditional mortar and plastering, tiles, reinforcement bars, timber, doors, and window frames. The constructional system used in traditional house is basically bearing walls system and domes usage in roofing, which is characterised by the diversity of forms (cradle dome, Bakdashya dome,

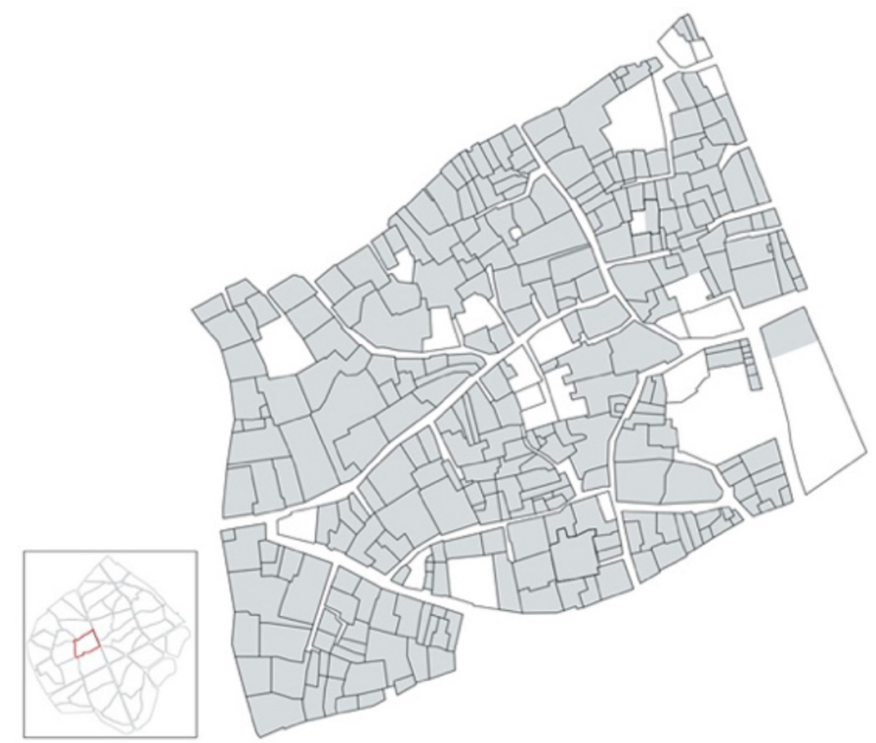

Fig. 6. A close up to one of the blocks of the Old City.

Tisht dome). One of the most common structural building materials in the vernacular architecture is flint stone, plaster, marble, limestone (Al Hillan). Marble is widely used in the vernacular architecture in the Old City in Al Dallayat, pillars and arches which consist of ornamental elements. Also, its used in doors and windows frames for decorations with various styles of ornaments such as: $\mathrm{Al}$ Adl, Al Door, Al Kassami, Al Kakhma, Thu-Nabain Wa-Miftah). Likewise, marble is used in other parts of the house including Iwan area, walls overlooking the courtyard and internal walls for decorative niches in the walls and corners, cornices, and cladding (Fig. 7). Al Hillan (limestone) is used in open areas unlike Marble. Other materials such as ceramic, wood, brick, and others are also used in some units in the Old City. 


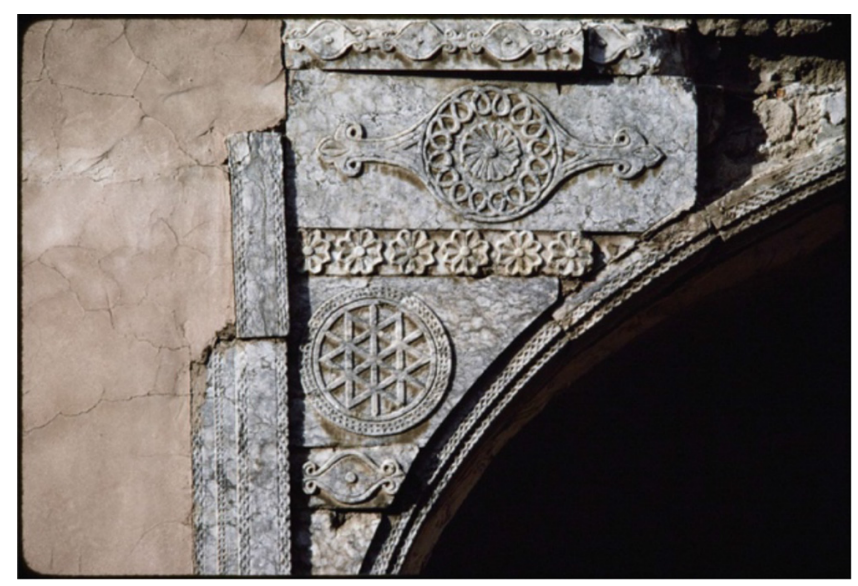

Fig. 7. Mosulian Marble used in decorating arches in one the houses in Mosul [Mosul eye].

Historic landmarks sites (Fig. 8) like Al Nuri Mosque need to be protected urgently for containing historic interior details that are currently mixed with ordinary rubble and some sites are being used as rubble dumps. (The unsupervised disposal of rubble jeopardizes the recovery of important landmarks, valuable historic items such as pillars, window frames and other decorative elements Mosulian marble (Al farsh) or limestone (Al Hillan) are likely to be lost as it is being included with ordinary residential rubble (UN-Habitat) (Fig. 9).

The United Nations environmental programme (UNEP) reported that there are 7.65 tonnes of rubble in Mosul metropolitan area, $75 \%$ of which is located in west Mosul. However, the estimation of construction rubble in the Old City is crucial for providing adequate decisions for a sustainable rubble management including reclaim, reuse and recycling $[11,12]$.

There are few available literatures about construction rubble quantification methods. But given the data provided by the UN agencies in Mosul and government officials we have estimated the rubble generated from residential buildings in the Old City. By defining the types of residential buildings in the Old City and the rubble generated from each type according to their area and number of floors, then apply it to the number of destroyed buildings of each residential building type. Finally calculating the results of the residential buildings with the commercial buildings, public administrations and religious buildings (as shown in the below Tabs. 2 and 3).

In many areas in the Old City rubble is mixed with nonreusable and non-recyclable items as the local residents use these lands to throw their household waste. In this case, the cost and effort in sorting the waste into reusable and recyclable materials can be excessive as compared to the benefits [11] (Fig. 10).

Clean rubble may arise where the originating structure has been soft stripped or where source separation of the non-recyclables is carried out during the demolition, often by a manual process [13]. As there is rubble generated from the damage that can be immediately available, there is also

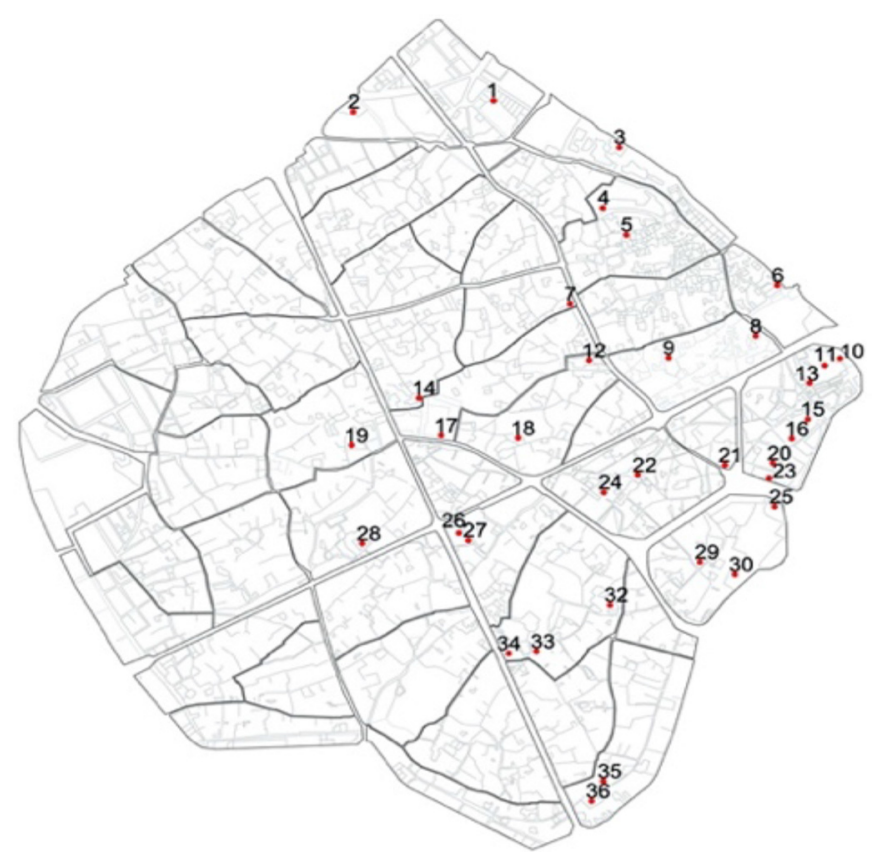

Fig. 8. Locations of the destroyed heritage landmarks. 1. EIisa Dadah shrine 2. Imam Abdulrahman shrine 3. Shekh Al Shat tomb 4. Al Umawi mosque 5. Omawi mosque minarat 6. Primary house of Iraqi 7. Emam Ibrahim mosque 8. Hammo Al Qaddo mosque 9. Catholic church 10. Al Aghawat mosque 11. Al Sawwaf khan 12. Nabi Jarjis mosque 13. Al Basha mosque 14. Al Hadbaa minarat 15. Al Mufti khan 16. Hammo Al Qaddu khan 17. Al Nuri mosque 18. Saida Nifisa shrine 19. Shah Zanan shrine and tomb 20. Al Hagiyat Khan 21. Al Najafi street 22. Khangar Khashab mosque 23. General old police station 24. Al Totonch house museum 25. Al Hatra hawks square 26. Al Saah church 27. Dominican fathers' monastery 28. Monastery of Dominican nuns 29. Khuzam mosque 30. Ancient Nineveh wall 31. Al Rabiaa mosque 32. Imam Awn Aldin shrins 33. Obeid Aga bath 34. Omar Alaswad mosque 35. Al Omariyya mosque 36. Al Abaroqi mosque.

the unreleased rubble which needs to be demolished since the rubble generated from the destruction is not easy to be accessible (Fig. 10, right). This concept is critical as it underscores the importance of processes and actions which need to be carried out before the debris can be managed.

The total area of the Old City is approximately 250 ha. The Old City overall has been completely destroyed in different damage levels around its area. Rubble distribution has been defined in this paper according to area-based damage assessment approach.

Main axes in the Old City (Fig. 11), share commercial and historic importance, Nineveh Street access and $\mathrm{Al}$ Farooq axes. Both axes have become integral part of the surrounding urban fabric, also they are linked to a number of main streets such as Al Nabi Jarjees and some small important axes such as the street of $\mathrm{Al}$ Nuri Mosque and $\mathrm{Al}$ Makawi.

A list of heritage buildings, which can be considered an important, source for the urban development to the city of Mosul and to strength the dimensions of sustainability. 

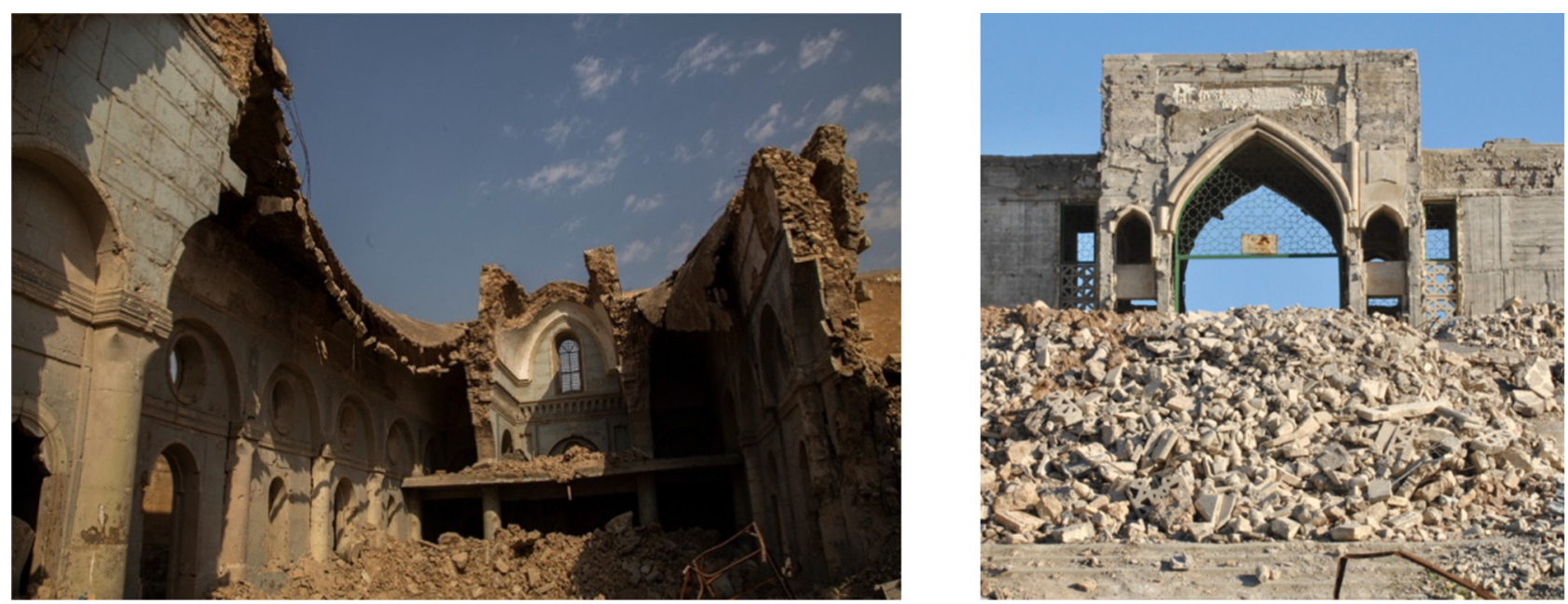

Fig. 9. Left - Mosul church (Al Saah Church) destruction [Mosul Eye]; Right: Unprotected historical materials and elements [Reuters].

Table 2. Residential building types in the Old City.

\begin{tabular}{llllll}
\hline Scale & & Floors & Occupants & $\mathrm{m}^{2}$ & Rubble generated (tones $\left./ 100 \mathrm{~m}^{2}\right)$ \\
\hline Old single-family house & $50 \%$ & 1 & 8 & 100 & 120 \\
Small single family & $10 \%$ & 2 & 4 & 100 & 80 \\
Common house & $20 \%$ & 2 & 6 & 200 & 100 \\
Large villa & $5 \%$ & 2 & 9 & 500 & 120 \\
\hline
\end{tabular}

Table 3. Estimated quantification of the total rubble generated in the Old City.

\begin{tabular}{|c|c|c|c|}
\hline \multirow[t]{2}{*}{ Building types } & \multicolumn{2}{|c|}{ Number of destroyed structures } & \multirow{2}{*}{$\begin{array}{l}\text { Total estimated rubble generation } \\
759480\end{array}$} \\
\hline & Destroyed/severe damaged & 5529 & \\
\hline Residential & Partly damaged & 9455 & 567300 \\
\hline Commercial & 111 & & 142080 \\
\hline Public administration & 38 & & 97280 \\
\hline Religious & 12 & & 14400 \\
\hline \multicolumn{3}{|c|}{ Total rubble estimated quantity in the Old City } & 1580540 ton \\
\hline
\end{tabular}
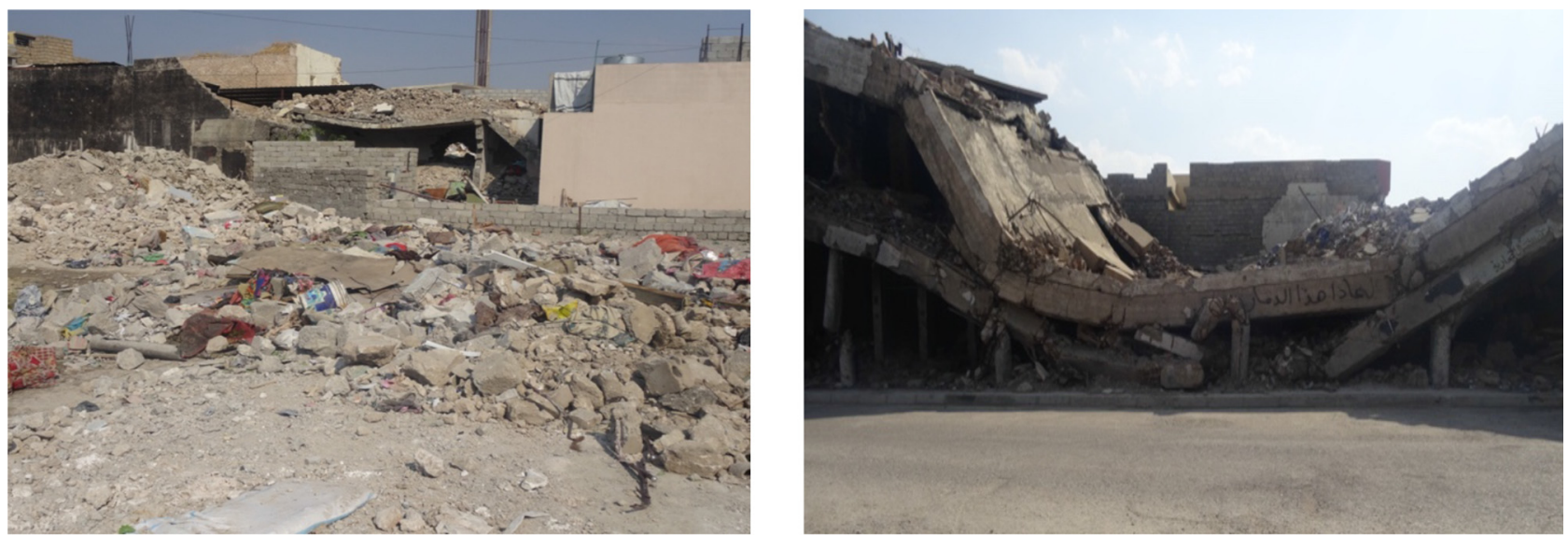

Fig. 10. Mixed rubble (left); Clean rubble (right). 


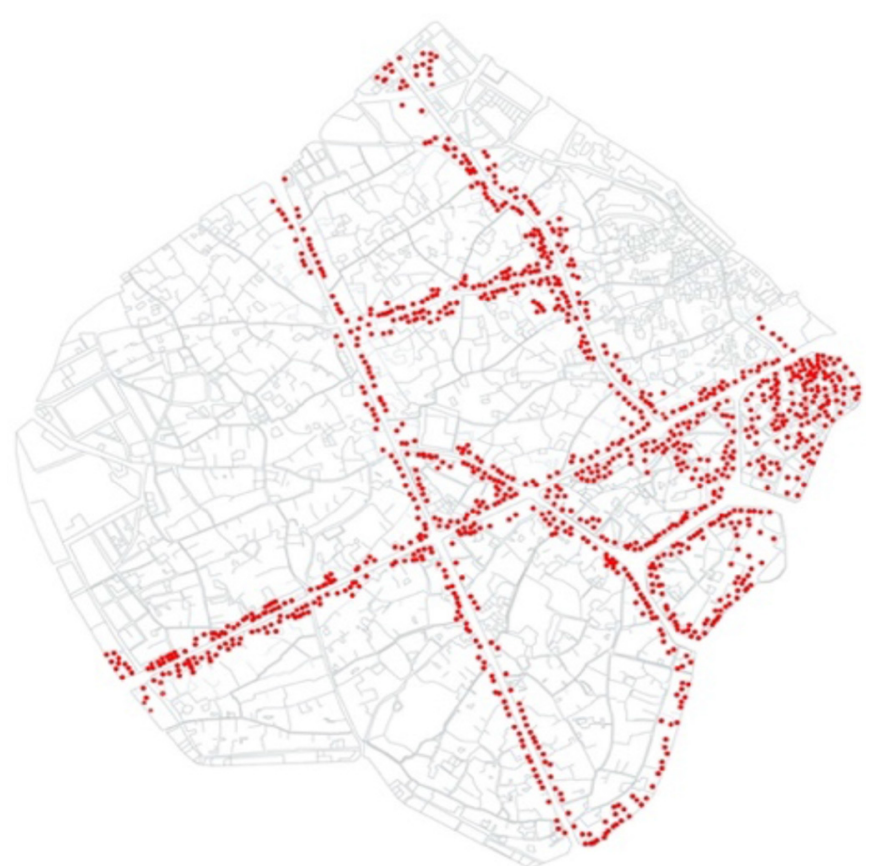

Fig. 11. Destroyed buildings on the main axes in the Old City.

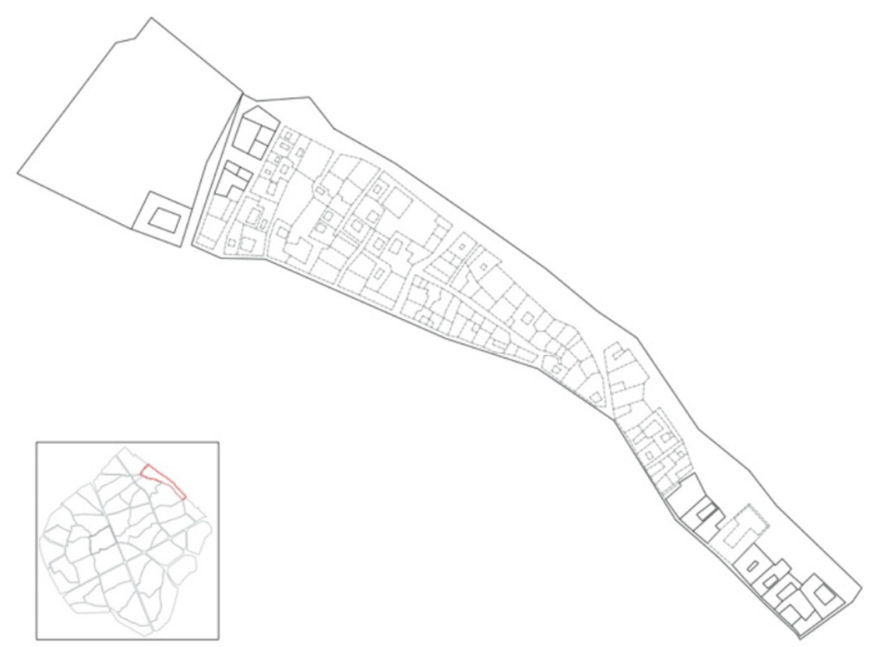

Fig. 12. Al Maidan riverfront area. Only the buildings in bold colour are the ones that are still standing up.

In addition, the preservation of building heritage in terms both maintenance and restoration, the importance of it is location within the old urban axis of the city and its role from the point of view of economic activities as well as its strategic location, which makes it versatile throughout the day [13].

Al Maidan riverfront in the Old City suffered from heavy destruction. According to the reports collected from the engineering bureau in Mosul, in this area there were approximately 2000 residential buildings: $62 \%$ of them (1244 units) were completely destroyed and the remaining $38 \%$ (761 units) were severely damaged (Fig. 12). Clearance operations have taken place by locals in October 2018 by local authorities and the military as they were making access for their movement. As a result, a substantial part of the rubble contaminated by ERW has been pushed onto the riverfront or into the Tigris River [9].

\section{Main results and recommendations}

The study shows that significant areas of the Old City with a high heritage value have been damaged and as a result they will require extensive rubble clearance. Blocks that have a significant number of traditional houses with high heritage value require additional supervision for their rehabilitation. However, not all buildings with historic value have been recorded. Furthermore, it is likely that low-cost reconstruction approaches carried out by unskilled locals will damage historic structures in these areas. The study recommends the following strategies to be taken by the local authorities to prevent further damage to the architectural heritage in Mosul and especially in the Old City area:

- Selective areas need to be immediately protected from further destruction especially while clearing and during rubble disposal.

- Specialized supervision by specialized heritage teams is demanded during the clearance in these areas. Unsupervised clearance should cease.

- The specialized heritage damage teams will identify buildings that should be saved, as well as heritage elements to be moved to a storage site in advance of continuing rubble clearance activities in selected areas in the Old City.

- In case no specialized heritage teams are available for supervising, the rubble clearance and the initial housing reconstruction activities should focus on areas with fewer historic buildings and less heritage value.

- The local authorities must define clearance protection zones and start supervised rubble clearance in selected areas.

- Temporarily stop the ongoing reconstruction activities along the riverfront of Al Maidan.

- Protection of vulnerable heritage sites from looting and weathering by restricting access, closing off sections, and protecting valuable interiors with tarpaulins or waterproof protective materials [9].

- The local authorities can elect some buildings as heritage storages in which locals and homeowners can temporarily store historic architectural elements that can be reused in the rehabilitation and reconstruction processs.

\section{Conclusion}

The Old City contains over 1.5 million tons of constructional rubble caused by the military strikes. Causing a significant environmental problem, heritage destruction and thousands of locals who lost their houses. Between the urgent need for those locals to return and the need to prevent further destruction to the environment and heritage, there is an increasing need for a supervised long-term reconstruction plan. 
The lack of public awareness along with the individuals' efforts to return demonstrates the need for a whole recovery campaign led by local authorities. Historic buildings must be protected immediately and some of them can be closed off. The ongoing self-rebuilding can be supported by providing rubble clearance guidelines, specifying disposal stations and recycling centres. Official approval and guidance must be enforced by the local authorities for the owners of the property before clearing the rubble.

The authors would like to warmly thank Dr. Muzahim Al Khayatt president of Nineveh University and the Committee responsible for the national effort to restore services in Nineveh governorate, Dr. Suhaib Yehya, head of consultancy engineering bureau in Mosul, UN-Habitat and UNDP in Iraq for their contributions. The authors wish to express gratitude to the Gulbenkian Foundation who supported the research.

\section{References}

1. D. Rumsfeld, The impact of war on Iraq's cultural heritage: operation Iraqi freedom, Cemml.colostate.edu

2. H. Matsunaga, The reconstruction of Iraq after 2003: learning from its successes and failures, World Bank Group, Washington, DC (2019)

3. K. Kadim, After years of war, Iraqis hit by frenzy of crime, Nbcnews.com. https://www.nbcnews.com/id/wbna32955876 (accessed February, 2019)
4. T. Susman, Civilian deaths may top 1 million, poll data indicate, latimes.com. https://www.latimes.com/archives/ la-xpm-2007-sep-14-fg-iraq14-story.html (accessed June, 2020)

5. J. Fawcett, V. Tanner, The internally displaced people of Iraq, The Brookings Institution-SAIS project, Washington (2002)

6. S. Youssef, History of Iraqi Architecture in Various Eras, (Al Rashid House for Publishing, Baghdad, Iraq (1982)

7. H.A. Kazem, M.T. Chaichan, Status and future prosperts of renewable energy in Iraq, Renewable Sustainable Energy Rev. 16, 6007-6012 (2012)

8. C. Machat, J. Ziesemer, Heritage at risk world report 20142015 on monuments and sites in danger (ICOMOS, Berlin, 2017). https://www.cemml.colostate.edu/cultural/09476/ chp04-12iraqenl.html (accessed February, 2018)

9. UN-Habitat, The initial planning framework for the reconstruction of Mosul, UN-Habitat, Mosul (2019)

10. United Nations Environmental Programme, Post conflict assessment, clean-up and reconstruction, United nations environmental programme in Iraq, Nairobi (2007)

11. A. Sayigh, Up-date renewable energy and climate change, Renew. Energy Environ. Sustain. 6 (2021)

12. M. Correia Guedes, Bioclimatic architecture in warm climates: a guide for best practices in africa, Springer, Cham, Switzerland (2019)

13. Consultancy Engineering Bureau, Reconstruction of the old city of Mosul: initial study, Consultancy Engineering Bureau, Mosul (2017)

Cite this article as: Hala Ali Abdulrazaq, Manuel Correia Guedes, Post-war sustainable housing design strategies: the case of reconstruction in Iraq, Renew. Energy Environ. Sustain. 6, 22 (2021) 